This is the accepted version of the article:

Adarsh N.N., Chakraborty A., Tarrés M., Dey S., Novio F., Chattopadhyay B., Ribas X., Ruiz-Molina D.. Ligand and solvent effects in the formation and self-assembly of a metallosupramolecular cage. New Journal of Chemistry, (2017). 41. : 1179 - . 10.1039/C6NJ 03456J.

Available at: https://dx.doi.org/10.1039/C6NJ 03456J 

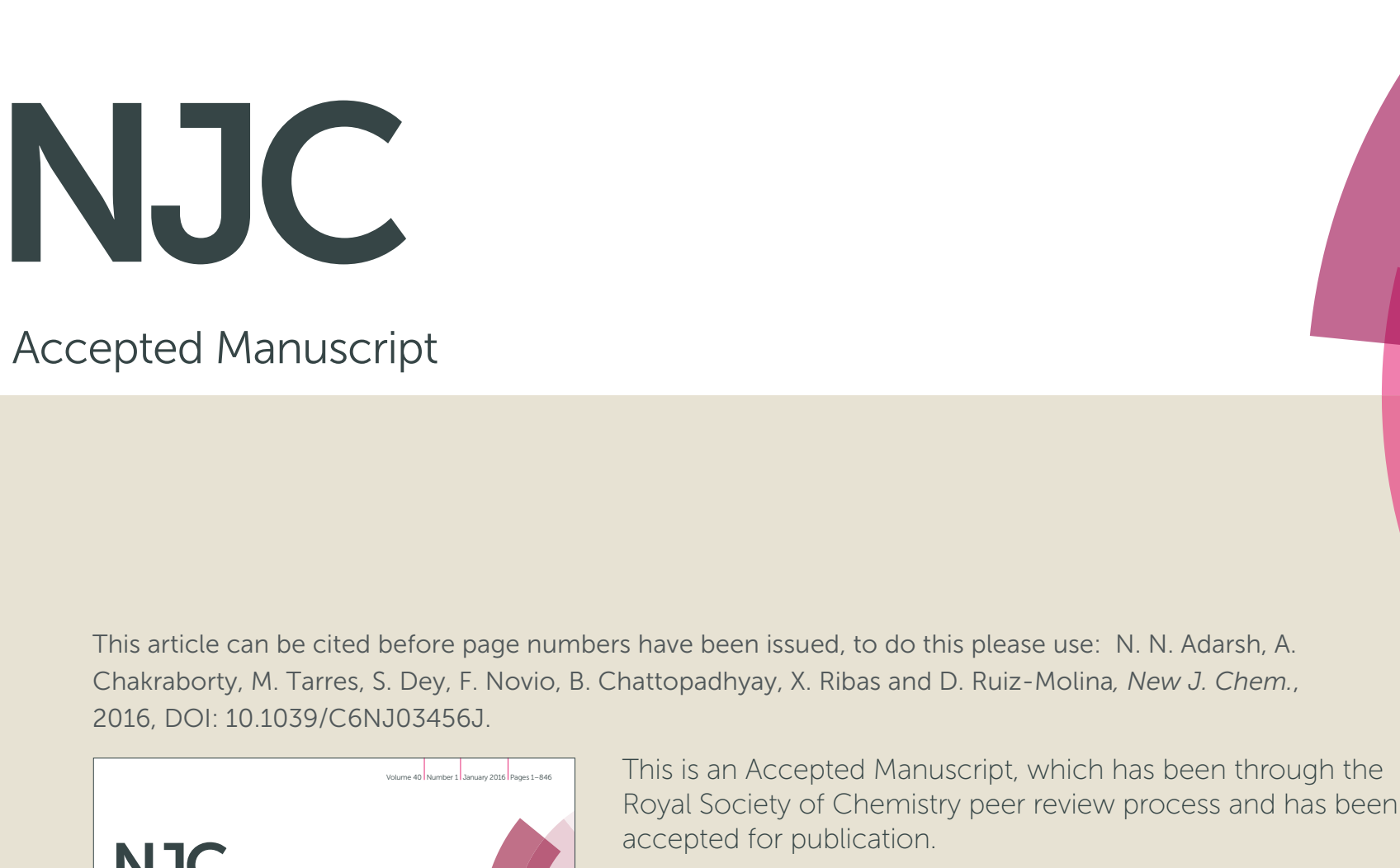

This article can be cited before page numbers have been issued, to do this please use: N. N. Adarsh, A. Chakraborty, M. Tarres, S. Dey, F. Novio, B. Chattopadhyay, X. Ribas and D. Ruiz-Molina, New J. Chem. 2016, DOI: 10.1039/C6NJ03456J.

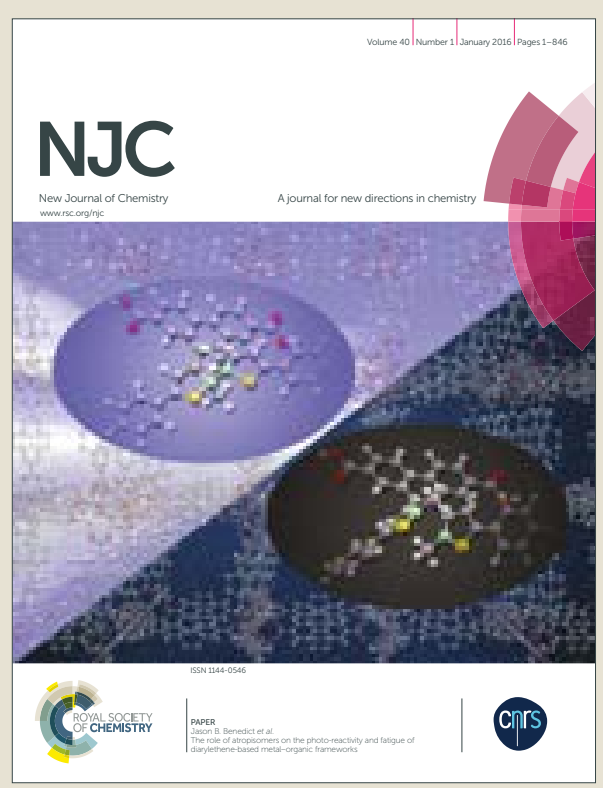

This is an Accepted Manuscript, which has been through the Royal Society of Chemistry peer review process and has been accepted for publication.

Accepted Manuscripts are published online shortly after acceptance, before technical editing, formatting and proof reading. Using this free service, authors can make their results available to the community, in citable form, before we publish the edited article. We will replace this Accepted Manuscript with the edited and formatted Advance Article as soon as it is available.

You can find more information about Accepted Manuscripts in the author guidelines.

Please note that technical editing may introduce minor changes to the text and/or graphics, which may alter content. The journal's standard Terms \& Conditions and the ethical guidelines, outlined in our author and reviewer resource centre, still apply. In no event shall the Royal Society of Chemistry be held responsible for any errors or omissions in this Accepted Manuscript or any consequences arising from the use of any information it contains. 


\title{
ARTICLE
}

\section{Ligand and solvent effects in the formation and self-assembly of a metallosupramolecular cage}

Received 00th January 20xx, Accepted 00th January 20xx

DOI: $10.1039 / x 0 \times x 00000 x$

www.rsc.org/

\author{
N. N. Adarsh, ${ }^{\mathrm{a}, \mathrm{b}} *$ Amarnath Chakraborty ${ }^{\mathrm{a}, \mathrm{c}} *$ Màrius Tarrés, ${ }^{\mathrm{d}}$ Surjendu Dey, ${ }^{\mathrm{a}, \mathrm{e}}$ Fernando Novio, \\ Basab Chattopadhyay, ${ }^{f}$ Xavi Ribas, ${ }^{d}$ Daniel Ruiz-Molina ${ }^{b, *}$
}

Two bis-pyridyl-bis-urea ligands namely $N, N^{\prime}$-bis-(3-pyridyl)diphenylmethylene-bis-urea (L1) and $N, N^{\prime}$-bis-(3picolyl)diphenylmethylene-bis-urea (L2) have been reacted with a $\mathrm{Cu}(I I)$ salt resulting in the formation of the metallosupramolecular cage $\left[\left\{\mathrm{Cu}_{2}(\mu-\mathrm{L} 1)_{4}(\mathrm{DMSO})_{2}\left(\mathrm{H}_{2} \mathrm{O}\right)_{2}\right\} \cdot \mathrm{SO}_{4} \cdot \mathrm{X}\right]$ (1) and the one dimensional coordination polymer $\left[\left\{\mathrm{Cu}(1)(\mu-\mathbf{L} 2)_{2}\left(\mathrm{H}_{2} \mathrm{O}\right)_{2}\right\}\left\{\mathrm{Cu}(2)(\mu-\mathbf{L} 2)_{2}\left(\mathrm{H}_{2} \mathrm{O}\right)_{2}\right\} \cdot 2 \mathrm{SO}_{4} \cdot 9 \mathrm{H}_{2} \mathrm{O} . \mathrm{X}\right]_{n}(2)$ (where DMSO = Dimethysulfoxide, $\mathrm{X}=$ disorder lattice included solvent molecules), respectively. The single crystal structures of $\mathbf{1}$ and $\mathbf{2}$ are discussed in the context of the effect of the ligands, hydrogen bonding functionality of ligand on the supramolecular structural diversities observed in these metal organic compunds. The supramolecular packing of the $\mathbf{1}$ is clearly influenced by the nature of the solvent and ligand used; mixtures of $\mathrm{DMSO} / \mathrm{MeOH}$ or $\mathrm{DMSO} / \mathrm{H}_{2} \mathrm{O}$ lead to the obtaining of blue crystals or a hydrogel, respectively.

\section{Introduction}

Metallosupramolecular cages (MSC) are formed by the coordination driven supramolecular self-assembly of metal ions and organic ligands, which depending on the stoichiometric ratio can lead to different architectures. ${ }^{1}$ Among these, the family of MSCs termed as $\mathbf{M}_{\mathbf{2}} \mathbf{L}_{\mathbf{4}}$ (where $\mathrm{M}=$ metal ion and $L=$ organic ligand) has attracted the attention of many researchers due to its simple and low symmetry structurally related to that of cryptands. ${ }^{2}$ Moreover, the nanoscopic cavities inside the cages of these materials have already been successfully used for several potential applications ranging from the encapsulation of environmentally relevant anions ${ }^{3}$ or cancer drugs such as cisplatin, ${ }^{4}$ to induce catalytic reactions, ${ }^{5}$ luminescence, ${ }^{6}$ separation techniques or the intracellular release of photosensitizers. $^{7}$

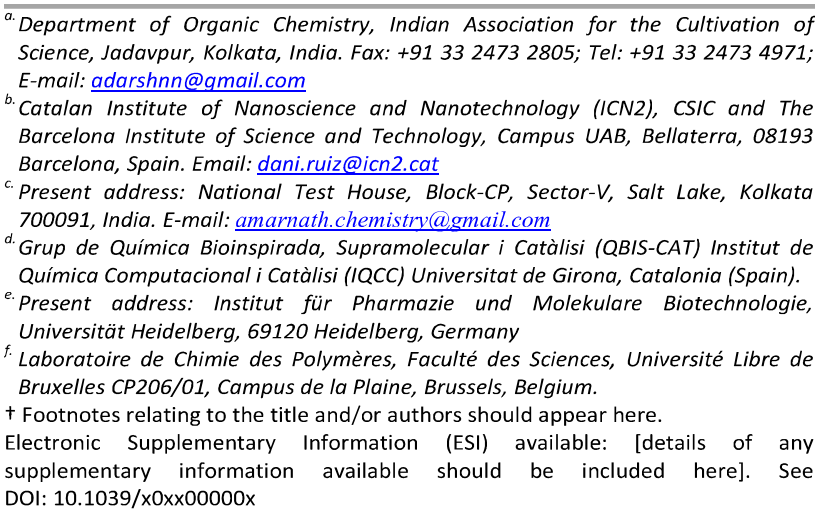

Coordination geometry of the metal center (octahedral or square planar) and the nature of the counter anions are relevant factors to control the formation of $\mathbf{M}_{\mathbf{2}} \mathbf{L}_{\mathbf{4}}$ cages. ${ }^{8}$ Though, it often results difficult to predict the final outcome of a properly pre-designed reaction to form $\mathbf{M}_{\mathbf{2}} \mathbf{L}_{\mathbf{4}}$ cages taking into account exclusively the aforementioned parameters; for this reason other factors must be considered. ${ }^{9}$ Among them, systematic studies that allow for a proper and judicious ligand and solvent selection represents one of the most challenging matters.

Herein we report a systematic study of two bis-urea-bis-pyridyl ligands, namely $N, N^{\prime}$-bis-(3-pyridyl)diphenylmethylene-bisurea (L1) and $N, N^{\prime}$-bis-(3-picolyl)diphenylmethylene-bis-urea (L2), the last having two additional carbon atoms and different conformational isomers (see Scheme 1 and ESI, S1). We will demonstrate how such minor modification strongly modifies the outcome of the reaction. While ligand $\mathbf{L 1}$ leads to the formation of a binuclear complex $\left[\left\{\mathrm{Cu}_{2}(\mu-\right.\right.$ $\left.\left.\left.\mathrm{L1}_{4}\right)_{4}(\mathrm{DMSO})_{2}\left(\mathrm{H}_{2} \mathrm{O}\right)_{2}\right\} \cdot \mathrm{SO}_{4} \cdot \mathrm{X}\right]$ (1) with a $\mathbf{M}_{2} \mathrm{~L}_{4}$ cage structure, model ligand $\mathbf{L 2}$ used for comparison purposes, yields a polymeric structure with general formulae $[\{\mathrm{Cu}(1)(\mu-$ $\left.\left.\mathbf{L 2})_{2}\left(\mathrm{H}_{2} \mathrm{O}\right)_{2}\right\}\left\{\mathrm{Cu}(2)(\mu-\mathrm{L} 2)_{2}\left(\mathrm{H}_{2} \mathrm{O}\right)_{2}\right\} \cdot 2 \mathrm{SO}_{4} \cdot 9 \mathrm{H}_{2} \mathrm{O} \cdot \mathrm{X}\right]_{\mathrm{n}}$ (2). Moreover, the supramolecular organization of $\mathbf{1}$ is tuned, thanks to the capability of ligand $\mathbf{L 1}$ to form hydrogen bonds through the urea groups, ${ }^{10,11}$ representing such control an issue of increasing relevance in crystal engineering. ${ }^{9}$ For instance, use of $\mathrm{DMSO} / \mathrm{MeOH}$ as solvent reaction leads to the formation of blue single crystals while the use of $\mathrm{DMSO} / \mathrm{H}_{2} \mathrm{O}$ results in the formation of a hydrogel G1.

\section{Results and discussion}

Ligand effect 
A methanolic solution of $\mathrm{CuSO}_{4} \cdot 5 \mathrm{H}_{2} \mathrm{O}$ was layered over a DMSO solution of $\mathbf{L 1}$ (details in experimental section) and kept at ambient condition for approximately one week. The resulting crystalline material was subjected to various physicochemical studies including single-crystal $\mathrm{X}$-ray diffraction (SXRD) and characterized as $\left[\left\{\mathrm{Cu}_{2}(\mu-\right.\right.$ L1 $\left.\left.)_{4}(\text { DMSO })_{2}\left(\mathrm{H}_{2} \mathrm{O}\right)_{2}\right\} \cdot \mathrm{SO}_{4} \cdot \mathrm{X}\right](\mathbf{1})$.

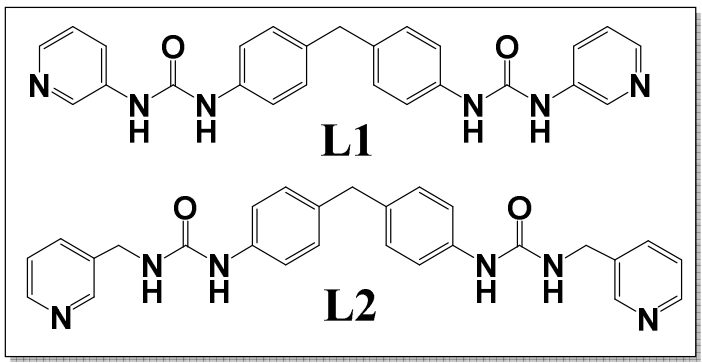

Scheme 1. Chemical structure of ligands $\mathbf{L}$ and $\mathbf{L} \mathbf{2}$
The dark blue colored octahedral crystals of 1 crystallize in a centrosymmetric tetragonal space group $14 / m$ (Table 1 ). The asymmetric unit contains one fourth of a metal center $\mathrm{Cu}(\mathrm{II})$, one fourth of a molecule of water (disorder over two positions), one fourth of a molecule of dimethyl sulfoxide (DMSO) (both DMSO and water were coordinated to $\mathrm{Cu}(\mathrm{II})$ ), one fourth of a non-coordinated sulfate anion (all are located on a four fold axis), a half molecule L1 (the central carbon atom of the ligand L1 was positioned at the 2-fold symmetry axis and as a result, therefore only half of the ligand was located in the asymmetric unit) and some unaccounted electron densities (1031 e/A $\AA^{3}$ per unit cell) presumably coming from disordered solvent molecules. The $\mathrm{Cu}(\mathrm{II})$ metal center displays a slightly distorted octahedral geometry $[\angle \mathrm{N}-\mathrm{Cu}-\mathrm{N}=$ $\left.89.831(10)^{\circ} ; \angle \mathrm{N}-\mathrm{Cu}-\mathrm{O}=93.10(9)^{\circ}\right]$; the equatorial positions are occupied by the pyridyl $\mathbf{N}$ atoms of the $\mathbf{L} \mathbf{1}$ and the apical positions are coordinated by the DMSO and water molecule (water molecule is very weakly coordinated to the metal center because of the disorder of water molecules over two positions).

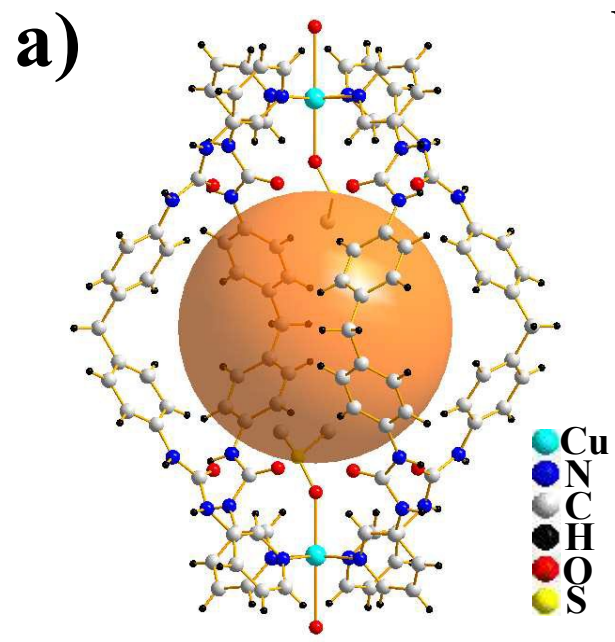

b)

c)

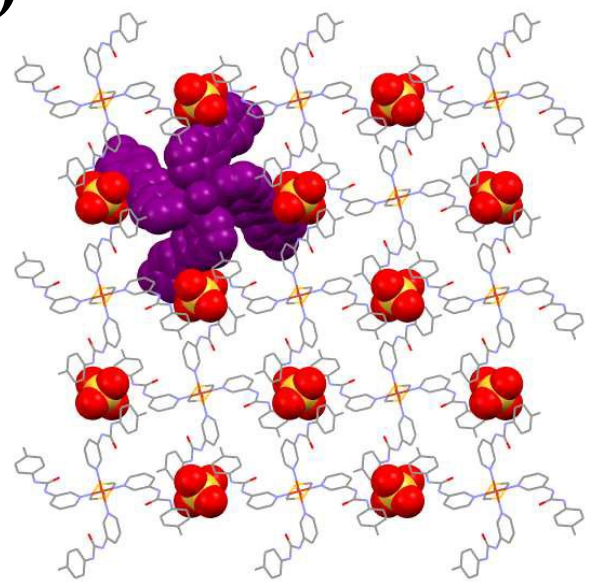

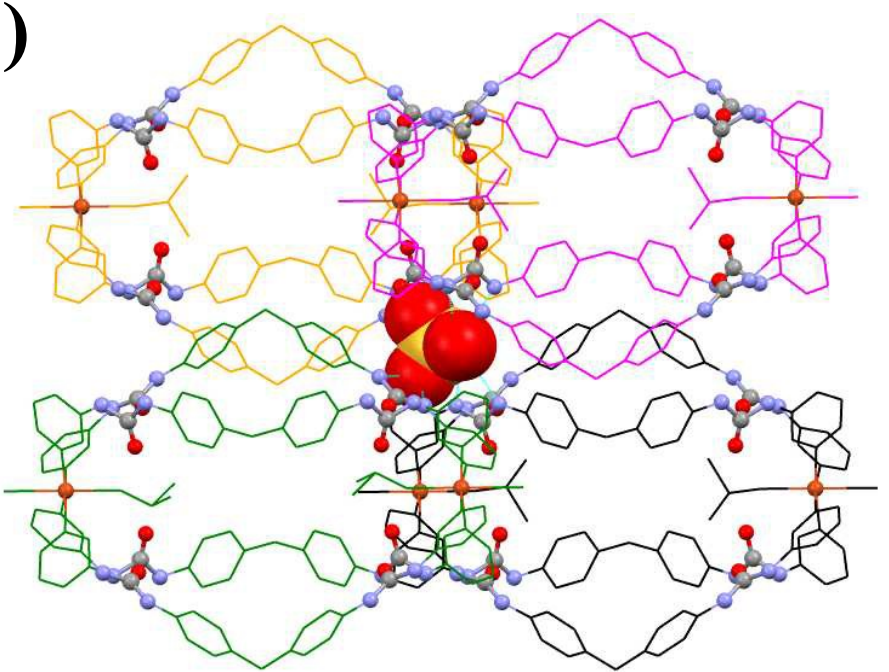

d)

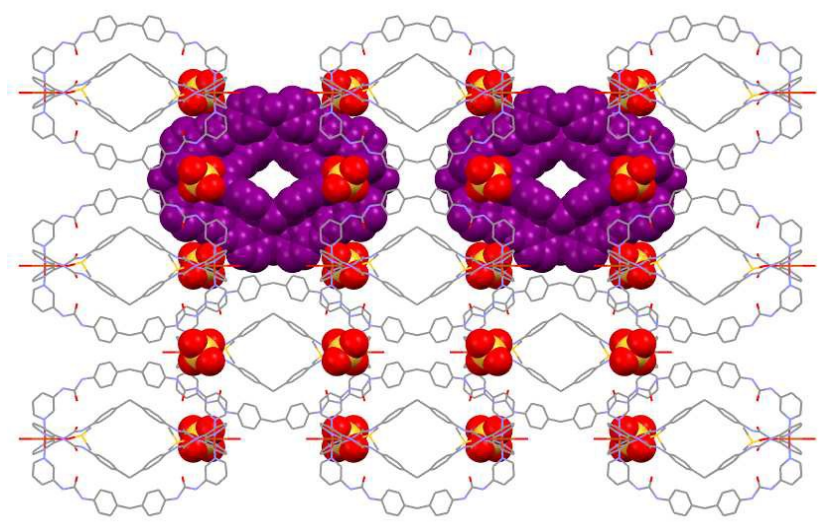

Figure 1. Crystal structure illustration of 1 - a) metallosupramolecular cage (orange sphere represent the void space within the cage); b) interaction of $\mathrm{SO}_{4}{ }^{2-}$ (orange-red color space-fill model) with urea moiety of four units of metallosupramolecular cage; c) and d) overall packing of 1 along the crystallographic axis "c" and " $b$ ", respectively. 


\section{ARTICLE}

The ligand $\mathbf{L 1}$ exhibits energetically more favorable syn-syn conformation around the central methylene carbon atom and keeping the urea $>\mathrm{C}=\mathrm{O}$ groups syn to each other. The terminal pyridyl moieties which were coordinated to the $\mathrm{Cu}$ (II) metal center were oriented in syn-syn fashion (relative to the adjacent urea $>\mathrm{C}=\mathrm{O}$ ) resulting in an angular ligating topology. The conformational (syn-syn-syn - Figure S1) dependent angular ligating topology of the ligand L1, metal : ligand ratio (1:2), and coordination mode of counter anion sulfate leads to the formation of a dinuclear Cu(II) MSC. Interestingly, the MSC has an oval shaped cage $[12.54 \times 4.3 \AA ̊$ by taking van der Waals radii into account] wherein all the urea $\mathrm{N}-\mathrm{H}$ moieties are pointed outwards and because of this reason the sulfate anion recognition inside the cage space is not taking place. Instead, the cage space was filled with metal bound DMSO molecules and other disordered lattice included solvent molecules. The sulfate counter anion is involved in hydrogen bonding with the urea functionality of $\mathbf{L 1}[\mathrm{N} . . . \mathrm{O}=2.893(5)-$ 2.954(5) $\AA$; $\angle \mathrm{N}-\mathrm{H}$...O $=157.2-160.6^{\circ}$ ] and each sulfate anion is involved in such hydrogen bonding with other four different MSCs leads to the formation of a three dimensional hydrogen bonded network structure (Figure 1, Table S1 - ESI+). Overall packing of the MSCs revealed the presence of channels running along crystallographic axis " $b$ " (Figure 1d). The presence of unaccounted electron density peaks were observed within such channels during the final cycles of refinement, which could not be model to any reasonable solvent molecule. Thus SQUEEZE ${ }^{12}$ calculations were carried out, which revealed that there were 515.5 electrons per asymmetric unit, which were attributed to solvents used for crystallization (8 DMSO, $7 \mathrm{MeOH}$ and 5.35 molecules of $\mathrm{H}_{2} \mathrm{O}$ ).

Thermogravimetric (TG) data of $\mathbf{1}$ indicated a weight loss of $30.9 \%$ within the temperature range of $26-159^{\circ} \mathrm{C}$ which could be attributed to the loss of lattice included and metal bound solvent molecules [calcd. weight loss for $5.35 \mathrm{H}_{2} \mathrm{O}$ (disordered) $+2 \mathrm{H}_{2} \mathrm{O}$ (metal bound) +8 DMSO (disordered) + 2 DMSO (metal bound) $+7 \mathrm{MeOH}=35.4 \%)]$. The difference in the calculated and experimental result may be due to the fast escape of disordered lattice included $\mathrm{MeOH}$ molecules (weight loss of $4.5 \mathrm{MeOH}=4.5 \%$ ) before loading the sample for TG experiment (Figure S3, ESI + ). Thus the TG data corroborated well with the SQUEEZE calculations (Figure S3 of the ESI).
Alternatively, a methanolic solution of $\mathrm{CuSO}_{4} \cdot 5 \mathrm{H}_{2} \mathrm{O}$ was also layered over a DMSO solution now of L2. After one week, a pale blue colored crystalline material was obtained. The resulting crystalline material was subjected to various physicochemical studies (see Experimental Section) including single-crystal $\mathrm{X}$-ray diffraction (SXRD) and characterized as $\left[\left\{\mathrm{Cu}(1)(\mu-\mathrm{L} 2)_{2}\left(\mathrm{H}_{2} \mathrm{O}\right)_{2}\right\}\left\{\mathrm{Cu}(2)(\mu-\mathrm{L} 2)_{2}\left(\mathrm{H}_{2} \mathrm{O}\right)_{2}\right\} \cdot 2 \mathrm{SO}_{4} \cdot 9 \mathrm{H}_{2} \mathrm{O} \cdot \mathrm{X}\right]_{n}$ The pale blue colored thin plate shaped crystals did not diffract beyond a $2 \theta$ of 270 (even after repeated data collections), reason why the structure was not anisotropically refined. The crystals belong to centrosymmetric triclinic space group $P$-1 (Table 1). The asymmetric unit contains two $\mathrm{Cu}(\mathrm{II})$ centers $[\mathrm{Cu}(1)$ and $\mathrm{Cu}(2)]$, two pairs of ligand L2, two pairs of water molecules (each pairs of ligands and water molecules were coordinated to metal centers $\mathrm{Cu}(1)$ and $\mathrm{Cu}(2)$ and form two different crystallographically independent units and some unaccounted electron densities (164 e/ $/ \AA^{3}$ per unit cell) presumably coming from disordered solvents.

The $\mathrm{Cu}$ (II) metal center displays a slightly distorted octahedral geometry; the equatorial positions are occupied by the pyridyl $\mathrm{N}$ atoms of the $\mathbf{L} \mathbf{2}$ and the apical positions are coordinated by water molecule.

\begin{tabular}{|c|c|c|}
\hline Crystal data & 1 & 2 \\
\hline CCDC Number & 913699 & 913700 \\
\hline Empirical formula & $\mathrm{C}_{122} \mathrm{H}_{186} \mathrm{Cu}_{2} \mathrm{~N}_{24} \mathrm{O}_{43} \mathrm{~S}_{13}$ & $\mathrm{C}_{108} \mathrm{H}_{146} \mathrm{Cu}_{2} \mathrm{~N}_{24} \mathrm{O}_{37} \mathrm{~S}_{2}$ \\
\hline Formula weight & 3220.81 & 2563.69 \\
\hline Crystal size (mm) & $0.32 \times 0.24 \times 0.18$ & $0.06 \times 0.02 \times 0.01$ \\
\hline Crystal system & Tetragonal & Triclinic \\
\hline Space group & $\mathrm{I} 4 / \mathrm{m}$ & P-1 \\
\hline a $(\AA)$ & $17.3071(6)$ & $14.456(5)$ \\
\hline $\mathrm{b}(\AA)$ & $17.3071(6)$ & 20.541(7) \\
\hline c $(\AA)$ & $28.5287(12)$ & $22.843(9)$ \\
\hline$\alpha\left(^{\circ}\right)$ & & 73.881(9) \\
\hline$\beta\left(^{\circ}\right)$ & & $79.477(10)$ \\
\hline$\gamma\left({ }^{\circ}\right)$ & & $88.620(9)$ \\
\hline Volume $\left(\AA^{3}\right)$ & $8545.4(6)$ & 6404(4) \\
\hline$Z$ & 2 & 2 \\
\hline Dcalc. $\left(\mathrm{g} / \mathrm{cm}^{3}\right)$ & 1.252 & 1.330 \\
\hline $\mathrm{F}(000)$ & 3392 & 2696 \\
\hline$\mu \operatorname{MoK} \alpha\left(\mathrm{mm}^{-1}\right)$ & 0.484 & 0.451 \\
\hline Temperature (K) & $100(2)$ & $100(2)$ \\
\hline Range of h, k, 1 & $-18 / 19,-19 / 20,-32 / 32$ & $-9 / 9,-13 / 13,-15 / 15$ \\
\hline$\theta \min / \max$ & $1.38 / 24.26$ & $0.94 / 13.69$ \\
\hline Reflections & & \\
\hline collected/unique/observed & $37895 / 3562 / 3154$ & 14199/3971/2892 \\
\hline Data/restraints/parameters & $3562 / 0 / 190$ & $3971 / 0 / 661$ \\
\hline Goodness of fit on $\mathrm{F}^{2}$ & 0.970 & 1.090 \\
\hline Final $R$ indices $[I>2 \sigma(I)]$ & $\mathrm{R}_{1}=0.0677$ & $\mathrm{R}_{1}=0.0964$ \\
\hline & $\mathrm{wR}_{2}=0.1993$ & $\mathrm{wR}_{2}=0.2381$ \\
\hline $\mathrm{R}$ indices (all data) & $\mathrm{R}_{1}=0.0787$ & $\mathrm{R}_{1}=0.1235$ \\
\hline & $\mathrm{wR}_{2}=0.2113$ & $\mathrm{wR}_{2}=0.2596$ \\
\hline
\end{tabular}


a)

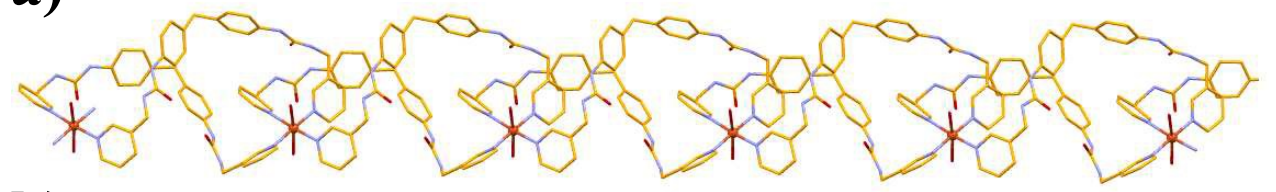

b)

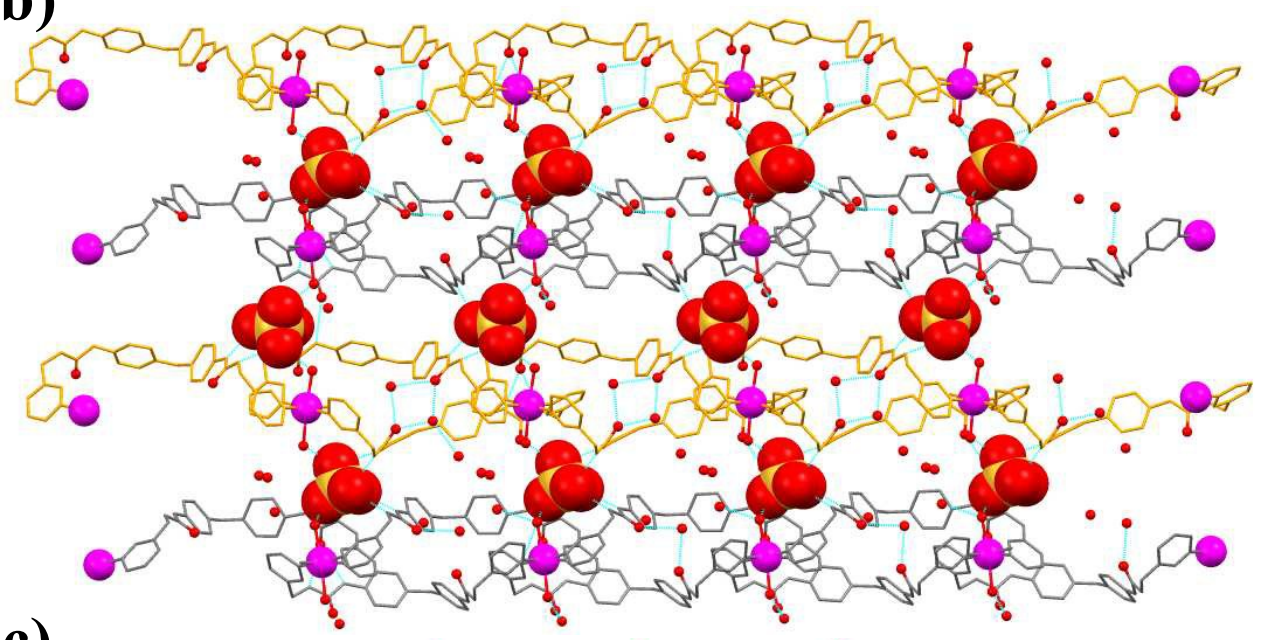

c)

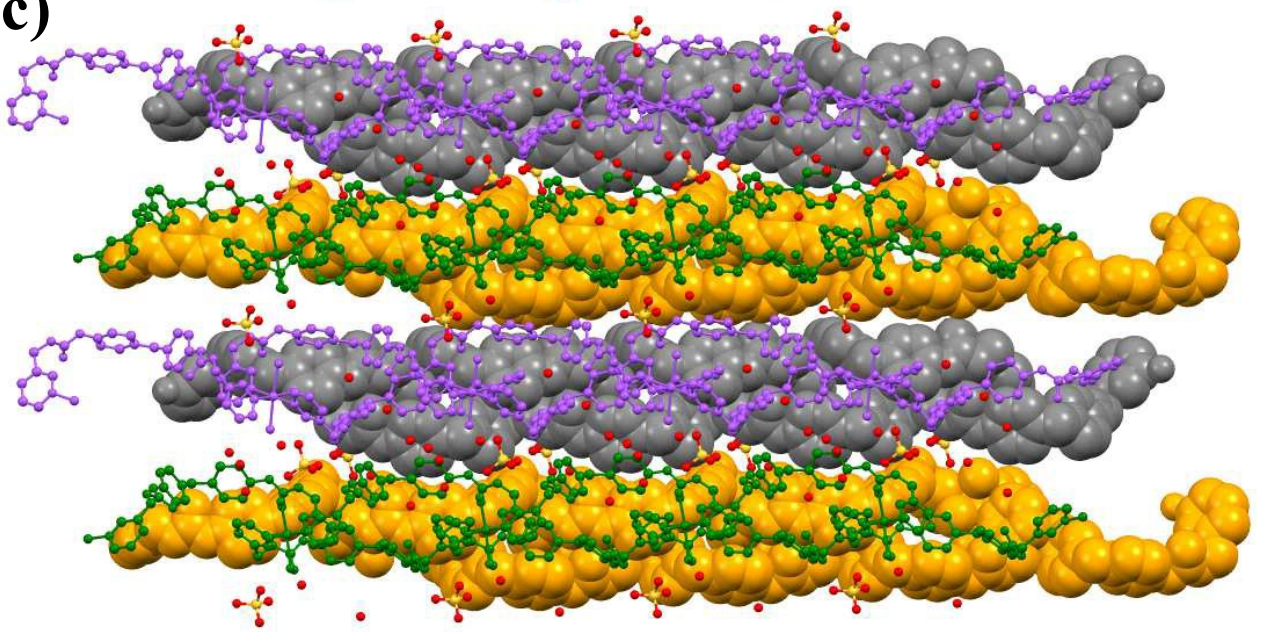

Figure 2. Crystal structure illustration of $\mathbf{2}-$ a) $1 \mathrm{D}$ looped chain $\mathrm{CP} ; \mathrm{b})$ two-dimensional hydrogen bonded sheet as a result of $\mathrm{SO}_{4}{ }^{2-}$ bridging of the $1 \mathrm{D}$ coordination polymeric looped chains (color code: $\mathrm{Cu}$ - magenta with space-fill model, O - red, $1 \mathrm{D} \mathrm{CP}$ loops - orange and grey, $\mathrm{SO}_{4}{ }^{2-}$ - red-orange with space-fill model); $\mathrm{c}$ ) overall packing of two dimensional sheets (alternate sheets are shown in grey-orange with space-fill model and purple-green with ball and stick model) via various hydrogen

The ligand L2 exhibits energetically less favorable syn-syn conformation around the central methylene carbon atom and keeping the urea $>\mathrm{C}=\mathrm{O}$ groups syn to each other (see ESI, Figure S2).

\section{Solvent effect}

As previously described, when the formation of complex 1 takes place in a DMSO/MeOH mixture, blue color block shaped single crystals are obtained. For comparison purposes, the reaction was repeated using now a DMSO/ $\mathrm{H}_{2} \mathrm{O}$ mixture. Replacement of $\mathrm{MeOH}$ by $\mathrm{H}_{2} \mathrm{O}$ from the DMSO mixture resulted in the formation of a gel (G1) stable under ambient conditions for more than a week, ${ }^{13}$ with a minimum gelator concentration (MGC) of $5.1 \mathrm{wt} \%$. Moreover, $\mathbf{G 1}$ did not show any thermo-reversible behavior indicating the coordination polymeric nature of the gel network.

As a representative example, the photographs of the hydrogel and single crystals obtained from reaction of $\mathrm{CuSO}_{4}$ with $\mathbf{~ L 1}$ under the two different conditions are shown in Figure 3. Morphological characterization by FE-SEM revealed the presence of a rough material with voids and wrinkles arising from agglomeration (Figure 4). Rheological response of G1 
using dynamic rheology was tested, displaying a typical gel-like rheological response. Note that $\mathbf{G}^{\prime}$ is independent of frequency and considerably higher than G" over the range of frequencies (see ESI, Figure S6). Worth to mention, Steed and coworkers reported the tuning nature of rheological property of $\mathrm{Cu}$ (II) and $\mathrm{Ag}^{\prime}$ gels derived from $\mathbf{L} \mathbf{1}$ based on the crystal structure of the gelator. ${ }^{14}$ In fact it is proved from the single crystal X-ray structure analysis study that the interaction of metal ions $\left(\mathrm{Cu}(\mathrm{II})\right.$ and $\left.\mathrm{Ag}^{\prime}\right)$ with pyridyl urea ligands induce gelation through metal cross-linked urea tape motif, or a metal crosslinked combination of urea tape and urea anion/urea solvent interactions. ${ }^{14 b}$ The crystal structures that we reported here also showed a directional hydrogen bonding interactions through urea...sulfate anion. Finally, indexing of the powder diffraction pattern of $\mathbf{G 1}$ using the program DICVOL06 ${ }^{15}$ showed a orthorhombic unit cell with $a=29.71(3), b=$ $18.89(2), \quad c=15.73(1) \AA ̊$; $\mathrm{Vol}=8825.63 \AA^{3}$, related though different to the tetragonal (ESI, Figure $\mathrm{S} 5$ ).

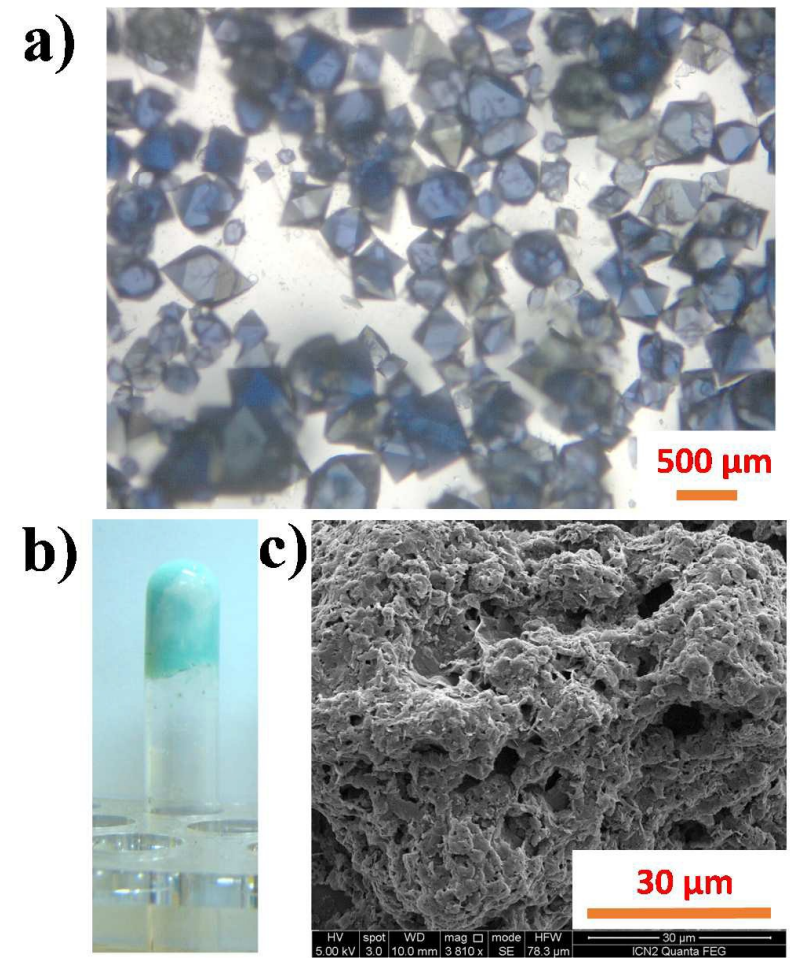

Figure 3. Photographs of the single crystals $\mathbf{1}$ (a) and gel $\mathbf{G 1}$ with the characteristic tube inversion (b). FE-SEM micrograph of the xerogel of G1 (c)

\section{Solvent-tuned morphology}

Finally, since the effect of solvent on the morphology of G1 was studied at room temperature and under air conditions using a 1 mol\% colloidal suspension of $\mathbf{G 1}$ treated with different solvents. For this, first aliquots of $\mathbf{G 1}$ were first dispersed in different solvent mixtures $\left(\mathrm{H}_{2} \mathrm{O}, \mathrm{CH}_{3} \mathrm{CN}-\mathrm{H}_{2} \mathrm{O}\right.$, $\mathrm{MeOH}-\mathrm{H}_{2} \mathrm{O}, \mathrm{CH}_{3} \mathrm{CN}$ and $\mathrm{CH}_{3} \mathrm{OH}$ ) and analyzed by SEM, TEM, and PXRD. Some of the results are shown in Figure 4. SEM images reveal that all the materials can be grouped into two morphologies: I) flakes, for samples obtained upon redispersion in $\mathrm{H}_{2} \mathrm{O}$ and related mixtures $\left(\mathrm{CH}_{3} \mathrm{CN}-\mathrm{H}_{2} \mathrm{O}\right.$ or $\mathrm{MeOH}-$ $\mathrm{H}_{2} \mathrm{O}$ ) and II) mixtures of nanoparticles and flakes for organic solvents such as $\mathrm{CH}_{3} \mathrm{CN}$ and $\mathrm{CH}_{3} \mathrm{OH}$. Energy dispersive X-ray (EDX) revealed the presence of copper metal ions for both flakes and nanoparticles, exhibiting in both cases a good match (see ESI, Figure S4). PXRD revealed that samples containing exclusively flake material exhibit the same crystalline pattern that the as-synthesized $\mathbf{G 1}$ sample.
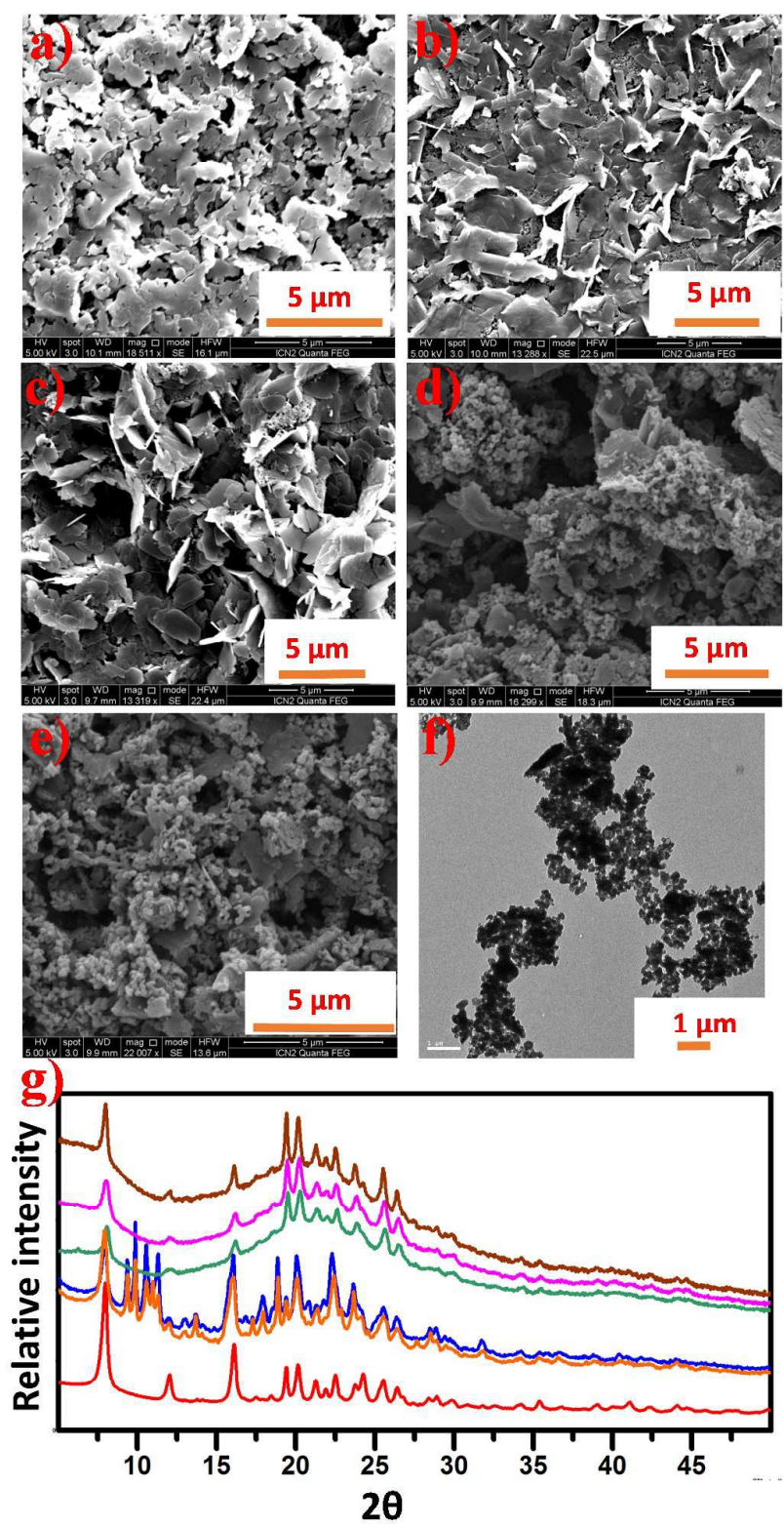

Figure 4. SEM pictures of the xerogel catalyst $\mathbf{G 1}$ obtained after reaction in various solvents - a) $\mathrm{H}_{2} \mathrm{O}$, b) $\mathrm{H}_{2} \mathrm{O}-\mathrm{MeOH}$, c) $\mathrm{H}_{2} \mathrm{O}-\mathrm{CH}_{3} \mathrm{CN}$, d) $\mathrm{CH}_{3} \mathrm{CN}$, e) $\mathrm{MeOH}$, f) TEM image of xerogel catalyst $\mathbf{G 1}$ obtained from $\mathrm{MeOH}$ displaying the nanoparticles; g) PXRD patterns of $\mathbf{G 1}$ under various conditions - color codes: red - as synthesized; orange and blue obtained from $\mathrm{MeOH}$ and $\mathrm{CH}_{3} \mathrm{CN}$ respectively; green, magenta and brown - obtained from $\mathrm{H}_{2} \mathrm{O}, \mathrm{H}_{2} \mathrm{O}-\mathrm{MeOH}$ and $\mathrm{H}_{2} \mathrm{O}-\mathrm{CH}_{3} \mathrm{CN}$ respectively. 
In the case of sample re-dispersion in $\mathrm{CH}_{3} \mathrm{CN}$ and $\mathrm{CH}_{3} \mathrm{OH}$, additional Bragg peaks are observed most likely arising from the nanoparticles though this fact cannot be fully confirmed since, in spite several different solvent mixtures were assayed, in none of the cases a sample containing the material nanostructured as pure nanoparticles was obtained. FT-IR confirm the chemical integrity of the cage 1 the different solvents (Figure S7, ESI).

\section{Conclusions}

In summary, we have demonstrated the supramolecular structural diversities as a function of the conformation of two analogous bis-urea-bis-pyridyl ligands L1 and L2. Minor differences in the nature of the ligands have been shown to strongly influence the final outcome of the reaction. While ligand $\mathbf{L} \mathbf{1}$ yields to the formation of the metallocage 1, ligand L2 leads to the formation of a 1-D coordination polymer. Moreover, the ability of ligand $\mathbf{L} \mathbf{1}$ to form supramolecular bonds through $\pi-\pi$ interactions, but mainly hydrogen bonds, has been afterwards used to obtain polymorphs with different morphologies, from single crystals to a gel or microcrystalline powder made of flakes and/or nanoparticles.

\section{Experimental}

\section{Materials and method}

All chemicals were commercially available (Aldrich) and used without further purification. The ligand $N, N^{\prime}$-bis-(3pyridyl)diphenylmethylene-bis-urea $\mathbf{L 1}$ was previously reported by Steed et al. ${ }^{14}$ and the ligand $N, N^{\prime}$-bis-(3picolyl)diphenylmethylene-bis-urea $\mathbf{L} \mathbf{2}$ was prepared by mixing 3-picoly amine and diphenylmethane-4,4'-isocyanate. The elemental analysis was carried out using a Perkin-Elmer 2400 Series-II CHN analyzer. FT-IR spectra were recorded using Perkin-Elmer Spectrum GX and TGA analyses were performed on a SDT Q Series 600 Universal VA.2E TA instrument. X-ray Powder Diffraction (PXRD) patterns were recorded on a Bruker AXS D8 Advance Powder ( $\mathrm{Cu} \mathrm{K} \alpha 1$ radiation, $\lambda=1.5406 \AA ̊$ ) X-ray diffractometer. Scanning electron microscopy (SEM) was recorded in a JEOL, JMS-6700F, Field Emission Scanning Electron Microscope. Rheology experiments were performed in SDT Q Series Advanced Rheometer AR 2000.

\section{Synthesis}

L1 ( $N, N^{\prime}$-bis-(3-pyridyl)diphenylmethylene-bis-urea): To a stirring solution of diphenylmethane-4,4'-isocyanate $(2 \mathrm{~g}, 7.9$ mmol) in dry dichloromethane solution, a solution of 3aminopyridine $(1.48 \mathrm{~g}, 15.8 \mathrm{mmol})$ in dry dichloromethane was added dropwise. The white colored turbid solution became a thick white precipitate, which was further stirred at room temperature for $24 \mathrm{~h}$. After filtration, the precipitate was washed with dichloromethane and air dried. The crude product thus obtained was then dissolved in DMF, and further addition of distilled water gave $\mathbf{L} \mathbf{1}$ as a precipitate, which was then filtered and air dried (3.2g, 70\% yield). Decomposed at
262으. Anal. Calcd for $\mathrm{C}_{25} \mathrm{H}_{25} \mathrm{~N}_{6} \mathrm{O}_{2}$ (\%): C, 68.48; $\mathrm{H}, 5.06 ; \mathrm{N}$, 19.17. Found: $\mathrm{C}, 64.40 ; \mathrm{H}, 5.22 ; \mathrm{N}, 18.67 .{ }^{1} \mathrm{H}$ NMR (300 MHz, DMSO- $\left.d_{6}\right): \delta=8.76(2 \mathrm{H}, \mathrm{s}$, urea $\mathrm{N}-\mathrm{H}), 8.69(2 \mathrm{H}, \mathrm{s}$, urea $\mathrm{N}-\mathrm{H})$, $8.57(2 \mathrm{H}, \mathrm{s}, \mathrm{Py}-\mathrm{H}), 8.16-8.15(2 \mathrm{H}, \mathrm{d}, J=3.0 \mathrm{~Hz}, \mathrm{Py}-\mathrm{H}), 7.92-7.90$ $(2 \mathrm{H}, \mathrm{d}, J=6.0 \mathrm{~Hz}, \mathrm{Py}-\mathrm{H}), 7.36-7.32(2 \mathrm{H}, \mathrm{d}, J=12.0 \mathrm{~Hz}, \mathrm{Ar}-\mathrm{H})$, 7.29-7.26 $(2 \mathrm{H}, \mathrm{dd}, J=3.0,6.0 \mathrm{~Hz}, \mathrm{Py}-\mathrm{H}), 7.12-7.08(2 \mathrm{H}, \mathrm{d}, J=$ $12.0 \mathrm{~Hz}, \mathrm{Ar}-\mathrm{H}), 3.80\left(2 \mathrm{H}, \mathrm{s},-\mathrm{CH}_{2}-\right)$ ppm. ${ }^{13} \mathrm{C} \mathrm{NMR}(300 \mathrm{MHz}$, DMSO- $\left.d_{6}\right)$ : $153.2(\mathrm{C}), 143.4(\mathrm{CH}), 140.6(\mathrm{CH}), 137.9(\mathrm{C}), 137.0$ (C), $136.0(\mathrm{C}), 129.5(\mathrm{CH}), 125.7(\mathrm{CH}), 124.2(\mathrm{CH}), 119.3(\mathrm{CH})$, $40.6\left(\mathrm{CH}_{2}\right)$ ppm. FT-IR (KBr pellet): $3302(\mathrm{~s}$, urea v N-H), 3178w, $3036(\mathrm{~m}$, aromatic $\vee \mathrm{C}-\mathrm{H}), 2937 \mathrm{w}, 1691 \mathrm{w}, 1651$ (s, urea $\vee \mathrm{C}=\mathrm{O})$, 1599 (s, urea $\delta \mathrm{N}-\mathrm{H}), 1558 \mathrm{~s}, 1531 \mathrm{~s}, 1512 \mathrm{~s}, 1481 \mathrm{~m}, 1419 \mathrm{~s}$, $1408 \mathrm{~m}, 1300 \mathrm{~m}, 1286 \mathrm{~m}, 1253 \mathrm{~m}, 1234 \mathrm{w}, 1219 \mathrm{w}, 1188 \mathrm{w}$, $1118 w, 1022 w, 902 w, 864 w, 773 \mathrm{~m}, 702 \mathrm{~m}, 632 \mathrm{w}, 619 \mathrm{w} \mathrm{cm}{ }^{-1}$. MS calcd for $\mathrm{C}_{15} \mathrm{H}_{18} \mathrm{~N}_{6} \mathrm{O}_{2}[\mathrm{M}+\mathrm{H}]^{+}: 439.18$; found: 439.13 .

L2 (N,N'-bis-(3-picolyl)diphenylmethylene-bis-urea): To a stirring solution of diphenylmethane-4,4'-isocyanate $(2 \mathrm{~g}, 7.9$ $\mathrm{mmol}$ ) in dry dichloromethane solution, a solution of 3picolylamine $(1.7 \mathrm{~g}, 15.8 \mathrm{mmol})$ in dry dichloromethane was added dropwise. The white colored turbid solution became a thick white precipitate, which was further stirred at room temperature for $24 \mathrm{~h}$. After filtration, the precipitate was washed with dichloromethane and air dried. The crude product thus obtained was then dissolved in DMF, and further addition of distilled water gave $\mathbf{L} \mathbf{2}$ as a gelly precipitate, which was then filtered and air dried ( $800 \mathrm{mg}, 70 \%$ yield). $\mathrm{mp} 196 \circ \mathrm{C}$. Anal. Calcd for $\mathrm{C}_{27} \mathrm{H}_{26} \mathrm{~N}_{6} \mathrm{O}_{2} \cdot 2 \mathrm{H}_{2} \mathrm{O}$ (\%): C, 64.53; $\mathrm{H}, 6.02 ; \mathrm{N}$, 16.72. Found: $\mathrm{C}, 64.82 ; \mathrm{H}, 5.92 ; \mathrm{N}, 16.42 .{ }^{1} \mathrm{H}$ NMR $(300 \mathrm{MHz}$, DMSO- $\left.d_{6}\right): \delta=8.49(2 \mathrm{H}, \mathrm{s}$, urea $\mathrm{N}-\mathrm{H}), 8.48(2 \mathrm{H}, \mathrm{s}, \mathrm{Py}-\mathrm{H}), 8.42$ $(2 \mathrm{H}, \mathrm{s}$, urea N-H), 7.68-7.66 $(2 \mathrm{H}, \mathrm{d}, J=6.0 \mathrm{~Hz}, \mathrm{Py}-\mathrm{H}), 7.34-7.30$ $(2 \mathrm{H}, \mathrm{dd}, J=3.0,6.0 \mathrm{~Hz}, \mathrm{Py}-\mathrm{H}), 7.28-7.26(2 \mathrm{H}, \mathrm{d}, J=6.0 \mathrm{~Hz}, \mathrm{Ar}-$ $\mathrm{H})$, 7.03-7.01 $(2 \mathrm{H}, \mathrm{d}, J=6.0 \mathrm{~Hz}, \mathrm{Ar}-\mathrm{H}), 6.61-6.59(2 \mathrm{H}, \mathrm{d}, J=6.0$ $\mathrm{Hz}, \mathrm{Py}-\mathrm{H}), 4.29-4.28\left(4 \mathrm{H}, \mathrm{d}, J=3.0 \mathrm{~Hz},-\mathrm{CH}_{2}-\right), 3.73\left(4 \mathrm{H}, \mathrm{s},-\mathrm{CH}_{2}-\right)$ ppm. ${ }^{13} \mathrm{C}$ NMR (300 MHz, DMSO- $\left.d_{6}\right): 155.9$ (C), $149.3(\mathrm{CH})$, 148.6 (CH), 138.8 (C), 136.5 (C), 135.5 (C), $135.1(\mathrm{CH}), 129.4$ $(\mathrm{CH}), 124.0(\mathrm{CH}), 118.6(\mathrm{CH}), 41.1\left(\mathrm{CH}_{2}\right), 40.6\left(\mathrm{CH}_{2}\right) \mathrm{ppm}$. FT-IR ( $\mathrm{KBr}$ pellet): $3304(\mathrm{~s}$, urea $\vee \mathrm{N}-\mathrm{H}), 3032(\mathrm{~m}$, aromatic $\vee \mathrm{C}-\mathrm{H})$, 2875w, 1635 (s, urea $\vee \mathrm{C}=\mathrm{O}), 1593$ (s, urea $\delta \mathrm{N}-\mathrm{H}), 1566 \mathrm{~s}$, $1510 \mathrm{~s}, 1481 \mathrm{~s}, 1465 \mathrm{~s}, 1427 \mathrm{~s}, 1408 \mathrm{~s}, 1301 \mathrm{~s}, 1240 \mathrm{~s}, 1230 \mathrm{~s}$, $1190 \mathrm{~m}, 1178 \mathrm{w}, 1105 \mathrm{~m}, 1057 \mathrm{~m}, 1028 \mathrm{~m}, 810 \mathrm{~m}, 773 \mathrm{~m}, 756 \mathrm{~m}$, $711 \mathrm{~s}, 661 \mathrm{~m}, 524 \mathrm{w} \mathrm{cm}{ }^{-1}$. MS calcd for $\mathrm{C}_{15} \mathrm{H}_{18} \mathrm{~N}_{6} \mathrm{O}_{2}[\mathrm{M}+\mathrm{H}]^{+}$: 467.22; found: 467.14 .

1: An aqueous methanolic solution of $\mathrm{CuSO}_{4} \cdot 5 \mathrm{H}_{2} \mathrm{O}(11.4 \mathrm{mg}$, $0.0455 \mathrm{mmol}$ ) was layered over a DMSO solution of L1 (40 mg, $0.091 \mathrm{mmol})$. After four days, dark blue colored octahedral shaped crystals of metalla-macro-tricylic cryptand $\mathbf{1}$ was obtained. Yield: $23 \mathrm{mg}$ (41\%) Anal. data calc. for $\mathrm{C}_{102} \mathrm{H}_{104} \mathrm{~N}_{24} \mathrm{O}_{22} \mathrm{Cu}_{2} \mathrm{~S}_{2} .8 \mathrm{H}_{2} \mathrm{O}$.2DMSO: C, 50.73; $\mathrm{H}, 5.30 ; \mathrm{N}, 13.39$; S, 5.11 Found: C, 50.74; H, 5.22; N, 13.20; S, 5.01 FT-I.R ( $\mathrm{KBr}$, $\left.\mathrm{cm}^{-1}\right)$ : $3276(\mathrm{sb}$, urea $\vee \mathrm{N}-\mathrm{H}), 3064(\mathrm{sb}$, aromatic $\vee \mathrm{C}-\mathrm{H}), 1703 \mathrm{~s}$, 1664 (s, urea v C=O), 1604, $1591(\mathrm{~s}$, urea $\delta \mathrm{N}-\mathrm{H}), 1514 \mathrm{~s}, 1523 \mathrm{~s}$, $1485 \mathrm{~s}, 1427 \mathrm{~s}, 1298 \mathrm{~s}, 1242 \mathrm{~s}, 1207 \mathrm{~s}, 1116$ ( $\mathrm{s}$, sulfate $\vee \mathrm{S}=0$ ), 1064 s, 1020s, 952w, 912w, 806m, 700m, 649w, 611w, 501w $\mathrm{cm}^{-1}$.

2: An aqueous methanolic solution of $\mathrm{CuSO}_{4} \cdot 5 \mathrm{H}_{2} \mathrm{O}(13.4 \mathrm{mg}$, $0.0535 \mathrm{mmol}$ ) was layered over a DMSO solution of $\mathbf{L 2}(50 \mathrm{mg}$, $0.107 \mathrm{mmol}$ ). After one week, pale blue colored plate shaped 
crystals of $\mathbf{2}$ were obtained. 2: Anal. data calc. for $\mathrm{C}_{54} \mathrm{H}_{60} \mathrm{~N}_{12} \mathrm{O}_{16} \mathrm{Cu}_{2} \mathrm{~S}_{2} .8 \mathrm{H}_{2} \mathrm{O}: \mathrm{C}, 44.17 ; \mathrm{H}, 5.22 ; \mathrm{N}, 11.45$ Found: $\mathrm{C}$, 44.47; H, 5.02; N, 11.84. FT-I.R $\left(\mathrm{KBr}, \mathrm{cm}^{-1}\right)$ : 3410 (sb, water v O$\mathrm{H}), 3315(\mathrm{sb}$, urea $\vee \mathrm{N}-\mathrm{H}), 3086(\mathrm{sb}$, aromatic $\vee \mathrm{C}-\mathrm{H}), 2910 \mathrm{~m}$, 1691 (s, urea $\vee \mathrm{C}=\mathrm{O}), 1618(\mathrm{~s}$, urea $\delta \mathrm{N}-\mathrm{H}), 1560 \mathrm{~s}, 1489 \mathrm{~s}$, $1427 \mathrm{~s}, 1327 \mathrm{~s}, 1269 \mathrm{~s}, 1238 \mathrm{~s}, 1193 \mathrm{w}, 1107 \mathrm{~s}$ ( $\mathrm{s}$, sulfate $\vee \mathrm{S}=0$ ), $1095 \mathrm{~s} 1051 \mathrm{~s}, 802 \mathrm{~m}, 698 \mathrm{~m} \mathrm{~cm}^{-1}$.

\section{Single crystal X-ray diffraction.}

Single crystal X-ray data of $\mathbf{1}$ was collected using Mo $\mathrm{K} \alpha(\lambda=$ $0.7107 \AA$ A) radiation on a SMART APEX II diffractometer equipped with CCD area detector. Data collection, data reduction, structure solution/refinement were carried out using the software package of SMART APEX II. Synchrotron data for $\mathbf{2}$ was collected on the MX1 beamline operating at $\sim 16$ $\mathrm{keV}$ at the Australian Synchrotron, Australia. All structures were solved by direct method and refined in a routine manner. In most of the cases, non-hydrogen atoms were treated anisotropically. In most of the cases, hydrogen atom positions were generated by their idealized geometry and refined using a riding model; whenever possible, the hydrogen atoms associated with the lattice included solvents or metalcoordinated solvents were located and refined. Graphics were generated with MERCURY 2.3 and Diamond Version 3. CCDC codes of $\mathbf{1}$ and $\mathbf{2}$ are 913699 and 913700 , respectively.

\section{Acknowledgements}

We thank Department of Science \& Technology (DST), New Delhi, India for financial support. This work was also supported by project MAT2012-38318-C03-02 (to DR) and CTQ-201343012-P (to XR) from the Spanish Government and by FEDER funds. ICN2 acknowledges support from the Severo Ochoa Program (MINECO, Grant SEV-2013-0295). N.N.A, A.C and S.D thank IACS for research fellowships. N.N.A and A.C thank Prof. P. Dastidar and Prof. A. Sarkar for their valuable suggestions, support and help with the initial results. B.C. kindly acknowledges financial support from the FRS-FNRS (Belgian National Scientific Research Fund) for the POLYGRAD Project 22333186. B.C is a FRS-FNRS Research Fellow. Single crystal Xray diffraction of 1 was performed at the DST-funded National Single Crystal Diffractometer Facility at the Department of Inorganic Chemistry, IACS. We gratefully acknowledge Australian Synchrotron for providing MX1 beam line to collect the data of 2. SEM, PXRD and TEM were measured in Institut Català de Nanociència i Nanotecnologia (ICN2).

\section{Notes and references}

+ Electronic Supplementary Information (ESI) available: Hydrogen bonding parameters of $\mathbf{1}$, Conformational possibilities for ligands $\mathbf{L 1}$ and L2, TGA of crystals of $\mathbf{1}$, Rheology, SEM, TEM and EDX of xerogel G1, FT-IR comparison plot and crystallographic data in CIF format. See DOI: $10.1039 / \mathrm{b} 000000 \mathrm{x} /$

1 (a) L. Chen, Q. Chen, M. Wu, F. Jiang, and M. Hong, Acc. Chem. Res. 2015, 48, 201-210; (b) L. Xu, Y-X. Wang and H-B. Yang, Dalton Trans., 2015, 44, 867-890; (c) H. Amouri, C.
Desmarets, and J. Moussa, Chem. Rev. 2012, 112, 20152041; (d) M. B. Duriska, S. M. Neville, B. Moubaraki, J. D. Cashion, G. J. Halder, K. W. Chapman, C. Balde, J-F. Létard, K. S. Murray, C. J. Kepert and S. R. Batten, Angew. Chem. Int. Ed., 2009, 48, 2549-2552; (e) Y. Inokuma, T. Arai and M. Fujita, Nature Chem., 2010, 2, 780-783; (f) M. Paul, N. N. Adarsh and P. Dastidar, Cryst. Growth Des. 2014, 14, 1331-1337; (g) Z. Lu , C. B. Knobler, H. Furukawa, B. Wang, G. Liu and O. M. Yaghi, J. Am. Chem. Soc., 2009, 131 (35), 12532-12533.

2 (a) A. Schmidt, A. Casini and F. E. Kühn, Coord. Chem. Rev., 2014, 275, 19-36; (b) M. Han, D. M. Engelhard and G. H. Clever, Chem. Soc. Rev., 2014, 43, 1848-1860.

3 (a) L. J. Barbour, G. W. Orr and J. L. Atwood, Nature., 1998, 393, 671-673; (b) N. N. Adarsh, D. A. Tocher, J. Ribas and P. Dastidar, New J. Chem., 2010, 34, 2458-2469.

4 J. E. M. Lewis, E. L. Gavey, S. A. Cameron and J. D. Crowley, Chem. Sci., 2012, 3, 778-784.

5 J. E. M. Lewis, A. B. S. Elliott, C. McAdam, K. C. Gordon and J. D. Crowley, Chem. Sci., 2014, 5,1833-1843, b) M. D. Pluth , R. G. Bergman and K. N. Raymond, Acc. Chem. Res., 2009, 42 (10), pp 1650-1659

6 Y-B. Dong, P. Wang, J-P. Ma, X-X. Zhao, H-Y. Wang, B. Tang and R-Q. Huang, J. Am. Chem. Soc., 2007, 129, 4872-4873.

7 F. Schmitt, J. Freudenreich, N. P. E. Barry, L. JuilleratJeanneret, G. Süss-Fink and B. Therrien, J. Am. Chem.Soc. 2012, 134, 754-757

8 T. R. Cook and P. J. Stang, Chem. Rev., 2015, 115 (15), 70017045

9 a) G. R. Desiraju, Crystal Engineering: The Design of Organic Solids; Elsevier: Amsterdam, 1989; b) G. R. Desiraju, Angew. Chem., Int. Ed. Engl. 1995, 34, 2311; (d) G. R. Desiraju, Angew. Chem., Int. Ed. 2007, 46, 8342.

10 N. N. Adarsh and P. Dastidar, Chem. Soc. Rev., 2012, 41, 3039-3060

11 a) N. N. Adarsh, P. Sahoo and P. Dastidar, Cryst. Growth Des. 2010, 10, 4976-4986; b) D. Braga, S. d'Agostino, E. D'Amena and F. Grepioni, Chem. Commun., 2011, 47, 5154-5156; c) N. N. Adarsh and P. Dastidar, Cryst. Growth Des. 2011, 11, 328336.

12 A. L. Spek, J. Appl. Crystallogr. 2003, 36, 7.

13 a) P. Terech and R. G. Weiss, Chem. Rev., 1997, 97, 3133. b) P. Dastidar, Chem. Soc. Rev., 2008, 37, 2699; c) M-O. M. Piepenbrock, G. O. Lloyd, N. Clarke and J. W. Steed, Chem. Rev., 2010, 110, 1960. d) A. Ajayaghosh and V. K. Praveen, Acc. Chem. Res. 2007, 40, 644. e) D. K. Kumar and J. W. Steed, Chem. Soc. Rev., 2014, 43, 2080-2088. f) W. T. Truong, L. Lewis and P. Thordarson, "Biomedical Applications of Molecular Gels" in Functional Molecular Gels (Book Series: Soft Matter), Ed. J. F. Miravet and B. Escuder Gillier, Royal Society of Chemistry, Cambridge, UK, 2014, ch.6, pp. 156194.

14 a) L. Applegarth, N. Clark, A. C. Richardson, A. D. M. Parker, I. Radosavljevic-Evans, A. E. G<oeta, J. A. K. Howard and J. W. Steed. Chem. Commun. 2005, 5423-5425. b) P. Byrne, G. O. Lloyd, L. Applegarth, K. M. Anderson, N. Clarke and J. W. Steed, New J. Chem., 2010, 34, 2261-2274.

15 A. Boultifa and D. Louëra, J. Appl. Crystallogr. 2004, 37, 724731.

16 J. F. Miravet and B. Escuder, Chem. Commun., 2005, 57965798.

17 a) N. Zohreh, S. H. Hosseini, A. Pourjavadi, C. Bennett, Appl. Organometal. Chem., 2016, 30, 73-80; b) F. Nemati, M. M. Heravi, A. Elhampour, RSC Adv., 2015, 5, 45775-45784; c) S. Dadashi-Silab, B. Kiskan, M. Antonietti, Y. Yagci, RSC Adv., 2014, 4, 52170-52173; d) K. Bahrami, M. S. Arabi, New J. Chem., 2016, 40, 3447-3455. 
A metallosupramolecular cage and a one dimensional coordination polymer have been synthesized and structurally characterized by single crystal X-ray diffraction.

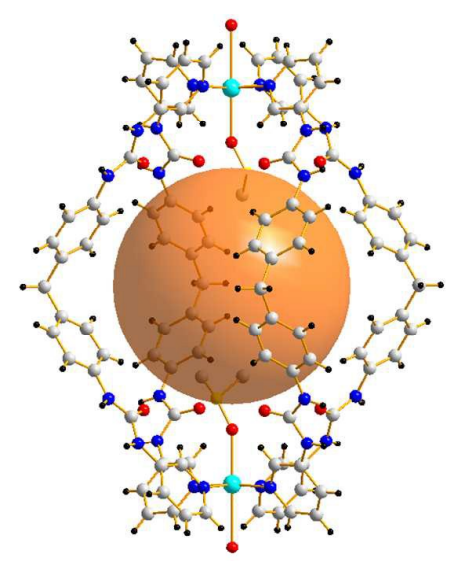

Metallosupramolecular cage

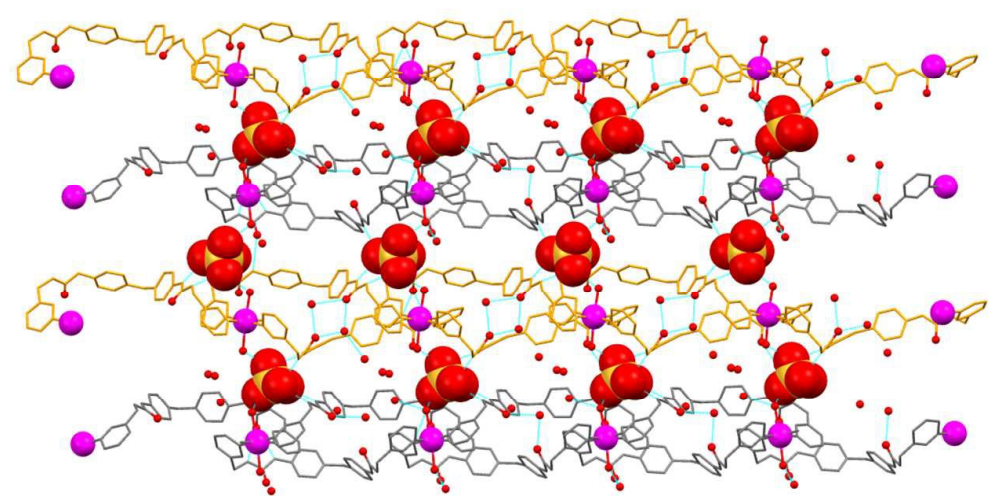

Coordination Polymer 